\title{
Funkcje badawcze w metodologii projektowania systemów organizacyjnych*
}

\section{Streszczenie}

Celem artykułu jest przedstawienie charakterystyki kluczowych funkcji badawczych, które stanowią podbudowę metodologiczną w projektowaniu organizatorskim. Wyróżniono następujące funkcje kluczowe: identyfikację, modelowanie wzorcujące, diagnozę, analizę prospektywną, podejmowanie decyzji projektowych. Każda z tych funkcji reprezentuje złożone postępowanie analityczne i poznawcze, w którym eksponuje się szczegółowe czynności (podfunkcje), specyficzne dla projektowania usprawniającego i bazowego. Jako kontekst funkcji badawczych przyjęto proces projektowo-realizacyjny.

W poszczególnych punktach artykułu została zaprezentowana następująca problematyka: nauka o projektowaniu a podejścia i metodyki organizatorskie, charakterystyka kluczowych funkcji badawczych, projektowanie usprawniające i bazowe, szczegółowe funkcje badawcze i administracyjne w procesie projektowo-realizacyjnym.

Słowa kluczowe: identyfikacja, modelowanie wzorcujące, diagnoza, analiza prospektywna, podejmowanie decyzji projektowych.

Klasyfikacja JEL: L20.

Adam Stabryła, Uniwersytet Ekonomiczny w Krakowie, Katedra Procesu Zarządzania, 31-510 Kraków, ul. Rakowicka 27, e-mail: adam.stabryla@uek.krakow.pl

* Artykuł powstał w wyniku realizacji tematu badawczego finansowanego ze środków przyznanych Wydziałowi Zarządzania Uniwersytetu Ekonomicznego w Krakowie w ramach dotacji na utrzymanie potencjału badawczego. 


\section{Wprowadzenie}

Projektowanie jest procesem, który wiąże merytorycznie funkcje kluczowe, będące $\mathrm{z}$ jednej strony złożonymi pracami analityczno-badawczymi, z drugiej zaś polegające na kreowaniu rozwiązań określonych zadań projektowych. Do funkcji kluczowych zaliczono: identyfikację, modelowanie wzorcujące, diagnozę, analizę prospektywną, podejmowanie decyzji projektowych. Zakres każdej z tych funkcji ma swoją specyfikę, która uwidacznia się w szczegółowych czynnościach (podfunkcjach) badawczych.

W metodologii projektowania należy uwzględnić zarówno uniwersalność określonych kanonów prowadzenia prac badawczych, jak i swoistość podejścia i stosowanych metodyk. Uniwersalność należy interpretować jako powszechność zasad i koncepcji, które są wspólne dla projektowania w dziedzinach technicznych, w sferze nauk ścisłych, a także w obszarze organizacji, zarządzania, ekonomii i innych. Swoistość natomiast jest wyróżnikiem odrębności postępowania badawczego oraz wykorzystywanych instrumentów (metod, technik, algorytmów).

Szczególnym przedmiotem projektowania są systemy organizacyjne, rozpatrywane zarówno w skali przedsiębiorstwa lub instytucji, jak i w makroskali, jako duże systemy gospodarcze, administracyjne, polityczne, militarne, a także organizacje społeczne.

Pod pojęciem systemów organizacyjnych będziemy rozumieć układy złożone, których charakterystyka jest następująca:

- ich podmiotowym odniesieniem są zespoły pracownicze, jednostki gospodarcze, instytucje,

- zakres przedmiotowy systemów organizacyjnych stanowią komponenty materialne i niematerialne,

- stanowią one konstrukcję spełniającą funkcje strukturalne, procesowe, koordynacyjne, motywacyjne i integracyjne,

- ich warstwę instrumentalną tworzą metody i techniki diagnostyczne, projektowe, decyzyjne, kontrolne, informatyczne i inne.

Do przykładów systemów organizacyjnych należą: struktura organizacyjna, system produkcji, system procesów technologicznych, system logistyki, system organizacji wirtualnej i sieciowej, system wiedzy, system informacyjny, system projektowania, system programowania zmian i rozwoju, system administracyjno-biurowy, system controllingu produkcji, system jakości.

Systemy organizacyjne są konstruktem dualnym: z jednej strony tworzą układ porządkująco-formalny (poprzez funkcje strukturalne, procesowe, koordynacyjne i inne - zob. wcześniej w tekście), z drugiej zaś zawsze są związane z określoną dziedziną lub sferą działalności. Ten dualizm sprawia, że systemy organizacyjne bardzo często występują w formach hybrydowych, a więc na 
przykład łącznie z systemami ekonomicznymi, technicznymi, informatycznymi [Metodologia projektowania... 2015, s. 39].

Należy ponadto podkreślić, że systemy organizacyjne stanowią szczególny rodzaj systemów zarządzania, obok systemów ekonomicznych (dziedzinowych, instrumentalnych), systemów operacyjnych (wytwórczych), systemów informatycznych. Traktowanie ich jako systemy zarządzania wynika $\mathrm{z}$ tego, że są one przyporządkowane procesom zarządzania i stanowią korelat pracy menedżerskiej.

\section{Nauka o projektowaniu a podejścia i metodyki organizatorskie}

Naukę o projektowaniu zdefiniujemy jako ogół wiedzy dotyczącej prac analityczno-badawczych i kreowania konstrukcji twórczych dla nowo tworzonych lub modyfikowanych obiektów i procesów. Zakres problematyki nauki o projektowaniu jest bardzo szeroki i, jak pisze W. Gasparski, obejmuje zagadnienia: „procesu projektowania, diagnostyki potrzeb, walorów rozwiązań projektowych, szczegółowych metod projektowania, przetwarzania informacji, twórczości w projektowaniu, sposobów komunikowania koncepcji i rozwiązań projektowych, weryfikowania tych koncepcji, oceny i wyboru rozwiązań, elementów inżynierii materiałowej, ergonomii, teorii systemów, teorii organizacji” [Gasparski 1970, s. 12]. Rozwinięte ujęcie treści nauki o projektowaniu przedstawiają H.A. Simon i S.A. Gregory (zob. tabela 1 i 2).

Tabela 1. Nauka o projektowaniu, czyli nauka o artefaktach według H.A. Simona

\begin{tabular}{|l|}
\hline \multicolumn{1}{|c|}{ Wyszczególnienie } \\
\hline Ocena wyników projektowania \\
1. Teoria oceny: teoria użyteczności, statystyczna teoria decyzji \\
2. Metody obliczeniowe \\
a) algorytmy wyboru rozwiązań optymalnych, takie jak algorytmy programowania linio- \\
wego, teoria sterowania, programowania dynamicznego, \\
b) algorytmy i procedury heurystyczne wyboru rozwiązań zadowalających. \\
Formalna logika syntezy \\
3. Logika klasyczna i deontyczna \\
Poszukiwanie alternatyw \\
4. Poszukiwanie heurystyczne: faktoryzacja i analiza środki-cele \\
5. Rozdział zasobów na poszukiwania \\
Teoria struktury i organizacja procesu projektowania \\
6. Systemy hierarchiczne \\
Teoria formułowania zadań projektowych
\end{tabular}

Źródło: opracowanie własne na podstawie: [Gasparski 1978, s. 47].

${ }^{1}$ Więcej na temat prezentowanej koncepcji - zob. [Stabryła 2006]. 
Tabela 2. Szczegółowa problematyka nauki o projektowaniu według S.A. Gregory’ego

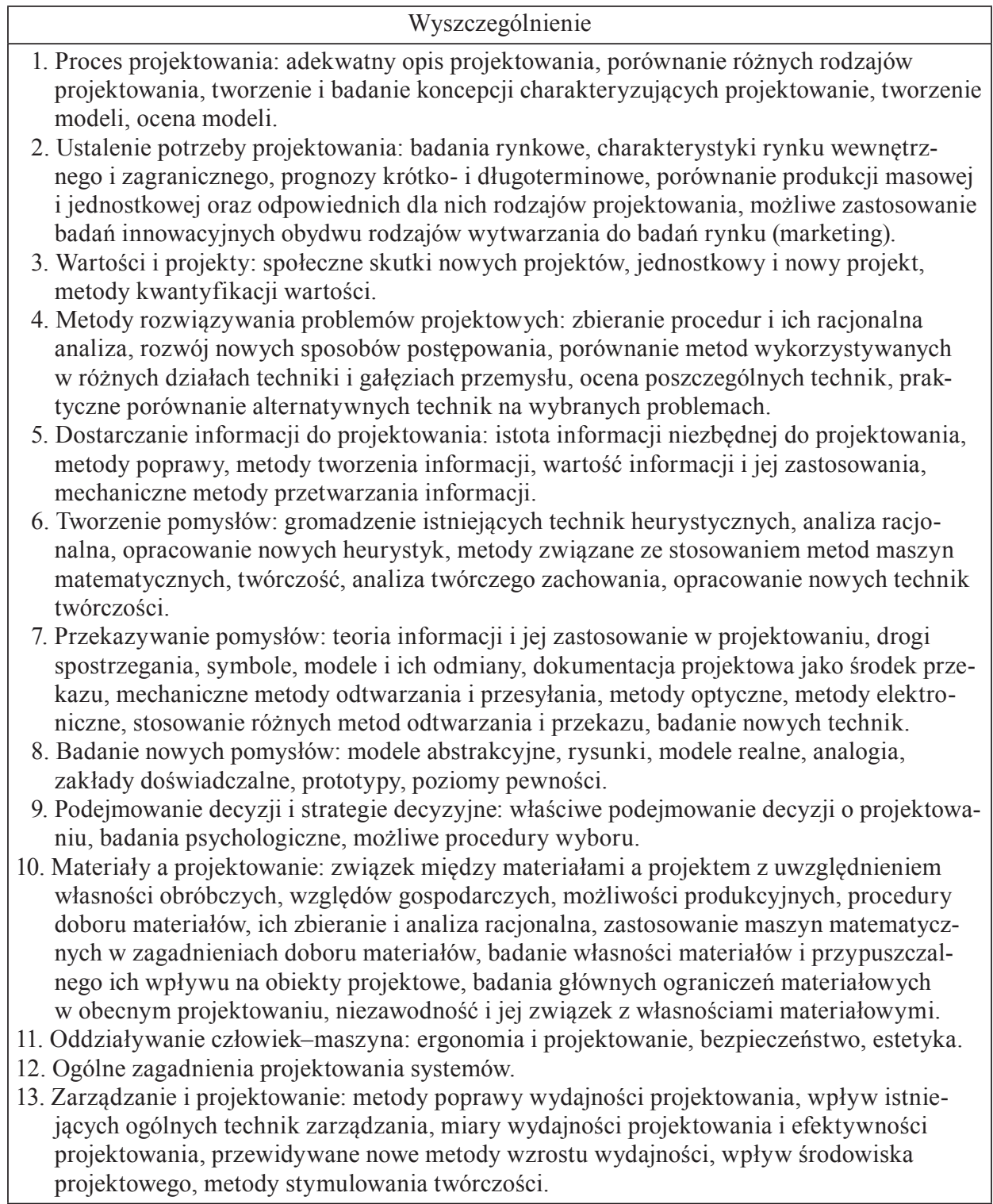

Źródło: opracowanie własne na podstawie: [Gasparski 1978, s. 42].

Rozległa problematyka nauki o projektowaniu znalazła swe odzwierciedlenie w różnych dziedzinach wiedzy i specjalizacjach zawodowych. Jej ważnym odniesieniem są podejścia badawcze w naukach o zarządzaniu, w szczególności trzy podejścia organizatorskie [Martyniak 1999, s. 12-13]: 
1) podejście opisowo-ulepszające,

2) podejście funkcjonalno-wzorcujące,

3) podejście diagnostyczno-funkcjonalne.

Podejście opisowo-ulepszające to najbardziej klasyczna strategia postępowania badawczego, której istotą jest identyfikacja i ocena stanu faktycznego obiektu (procesu), a następnie przeprowadzenie usprawnienia. Wyeliminowanie wad w funkcjonowaniu jakiegoś systemu, jak również jego udoskonalenie to dwa kierunki ulepszania.

Podejście funkcjonalno-wzorcujące eksponuje w badaniu funkcję (cel, zadanie, własność), nie zaś formę, a przede wszystkim wprowadza do postępowania wzorzec. Może być on konstrukcją idealną bądź rzeczywistą i stanowi probierz, do którego osiągnięcia zmierza postępowanie badawcze. W omawianym podejściu praktycznie została wyrugowana identyfikacja i ocena stanu faktycznego, zaś podstawą opracowania projektu jest model-wzorzec.

Podejście funkcjonalno-wzorcujące było kontestowane ze względu na odejście od krytycznej oceny i analizy i koncentrację na informacjach zewnętrznych, a pozostawienie na dalszym planie informacji wewnętrznych.

Podejście diagnostyczno-funkcjonalne jest wypadkową podejść wcześniej wyróżnionych i polega na uwzględnieniu w badaniu stadium opisowego oraz analizy funkcjonalnej i odniesienia wyników badań do modelu-wzorca.

Na podstawie określonych podejść - traktowanych jako strategie ideowe zostały wypracowane dwie generalne metodyki badawcze:

1) metodyka diagnostyczna,

2) metodyka prognostyczna.

Metodykę diagnostyczną najkrócej można streścić jako procedurę typową dla badań organizatorskich, skupiającą się na usprawnianiu procesów pracy. Sięga się przy tym do klasycznych technik o charakterze diagnostycznym, które są wykorzystywane w badaniu procesów produkcyjnych i administracyjnych [Martyniak 1999, Mikołajczyk 2001].

Odrębną koncepcją badawczą jest metodyka prognostyczna. Jej istotą jest projektowanie oparte na rozwiązaniu wzorcowym, przy czym metodyka prognostyczna może uwzględniać analizę stanu faktycznego [Trzcieniecki 1979].

Metodologia projektowania systemów organizacyjnych jest ukierunkowana na projektowanie usprawniające oraz na projektowanie bazowe. Kluczowe funkcje badawcze projektowania usprawniającego są właściwe dla metodyki diagnostycznej. Są to: identyfikacja, modelowanie wzorcujące, diagnoza, analiza prospektywna, podejmowanie decyzji projektowych. Natomiast projektowanie bazowe (odnoszące się do tworzonych dopiero systemów) jest osadzone w metodyce prognostycznej. W projektowaniu bazowym identyfikacja ma miejsce w ograniczonym zakresie (np. dotyczy informacji o stosowanych rozwiąza- 
niach wzorcowych), zaś nie występuje diagnoza. Pozostałe kluczowe funkcje są wspólne dla obydwu rodzajów projektowania.

Tabela 3. Ważniejsze elementy metodyki diagnostycznej i prognostycznej

\begin{tabular}{|l|l|}
\hline \multicolumn{1}{|c|}{ Metodyka diagnostyczna } & \multicolumn{1}{c|}{ Metodyka prognostyczna } \\
\hline $\begin{array}{l}\text { 1. Wybór przedmiotu badania: } \\
\text { - przewidywany cel rozwiązania, } \\
\text { - przewidywana efektywność rozwiązania, } \\
\text { - możliwości realizacji zamierzonego przed- } \\
\text { sięwzięcia organizacyjnego, }\end{array}$ & $\begin{array}{l}\text { 1. Ustalenie hipotezy budowy wzorca rozwią- } \\
\text { zania organizacyjnego: } \\
\text { - opłacalność prowadzenia badań. } \\
\text { - ogólne zorientowanie się w zakresie istnie- } \\
\text { jących rozwiązań wzorcowych. }\end{array}$ \\
$\begin{array}{l}\text { 2. Rejestracja stanu faktycznego (metody } \\
\text { dotychczasowej): zbieranie i porządkowanie } \\
\text { informacji. }\end{array}$ & $\begin{array}{l}\text { 2. Ustalenie zasad budowy wzorca rozwiąza- } \\
\text { nia organizacyjnego. }\end{array}$ \\
$\begin{array}{l}\text { 3. Ustalanie zasad oceny stanu faktycznego. } \\
\text { 3. Ustalenie wariantów rozwiązań wzor- } \\
\text { cowych i przeprowadzenie rozpoznania } \\
\text { możliwości ich realizacji. }\end{array}$ \\
$\begin{array}{l}\text { 4. Porównanie stanu faktycznego z norma- } \\
\text { tywnymi rozwiązaniami organizacyjnymi, } \\
\text { odpowiadającymi zasadom normatywnej } \\
\text { diagnozy. }\end{array}$ & $\begin{array}{l}\text { nybór wariantu racjonalnego (optymal- } \\
\text { 5. Ustalenie błędów organizacyjnych. } \\
\text { 6. Ustalenie wariantów usprawnień przez } \\
\text { eliminację błędów organizacyjnych. }\end{array}$ \\
$\begin{array}{l}\text { 7. Wybór wariantu racjonalnego (optymalnego). } \\
\text { 8. Opracowanie projektu organizacyjnego. } \\
\text { 9. Przeprowadzenie korekt projektu organiza- } \\
\text { cyjnego i wdrożenie projektu. }\end{array}$ & $\begin{array}{l}\text { 5. Opracowanie projektu organizacyjnego. } \\
\text { cyjnego i wdrożenie projektu. }\end{array}$ \\
\hline
\end{tabular}

Źródło: opracowanie własne.

W tabeli 3 przedstawione zostały główne elementy ramowego postępowania badawczego charakterystycznego dla metodyki diagnostycznej i prognostycznej.

\section{Charakterystyka kluczowych funkcji badawczych}

\subsection{Funkcja identyfikacji}

Identyfikacja w projektowaniu systemów organizacyjnych służy do prezentacji stanu faktycznego dowolnego obiektu, procesu lub zjawiska. Jest to więc funkcja polegająca na rozpoznaniu dziedziny badań należącej do obszaru, jaki określa organizację i funkcjonowanie danego systemu, jak również jego bliższe i dalsze otoczenie. Zakres identyfikacji może odnosić się na przykład do takich dziedzin jak: działalność operacyjna, potencjał technologiczny, zasoby ludzkie, aktywa finansowe. 
Charakterystyczne szczegółowe funkcje badawcze należące do zakresu identyfikacji to:

1) dobór rodzajowy i ilościowy determinant,

2) operacjonizacja determinant.

Determinanty pełnią funkcję opisową względem danej dziedziny badań i są wyrażone przez kategorie objaśniające oraz przez parametry i charakterystyki. Kategorie objaśniające to podstawowy zestaw pojęciowy dotyczący przedmiotu badań, zaś parametry i charakterystyki to wielkości, które są cechami ilościowymi lub jakościowymi określonej dziedziny. Parametry i charakterystyki mogą przyjmować także postać funkcji teoretycznych lub empirycznych. Szerokie zastosowanie w badaniach empirycznych mają charakterystyki czasowe.

Operacjonizacja jest funkcją polegającą na opracowaniu takich definicji terminów i złożonych tematów badawczo-projektowych, w których będą eksponowane metody i formuły pomiaru określonych cech (parametrów, zmiennych) wyróżnionych w zakresie identyfikacji danej dziedziny badań. Dzięki operacjonizacji uzyskuje się ścisłą i wyrazistą definicję projektu, określoną zarówno od strony interpretacyjnej samego tematu projektu, jak i ze względu na jego zakres przedmiotowy i funkcjonalny.

Przykładem struktury makiety identyfikacyjnej dla projektu „Programowanie rozwoju personalnego przedsiębiorstwa” jest następujący zakres tematyczny:

1) ruchliwość pracownicza,

2) wydajność pracy,

3) zdolność kierowania,

4) atmosfera pracy,

5) kwalifikacje zawodowe pracowników,

6) system karier zawodowych i kierowniczych,

7) jakość pracy,

8) system motywacyjny,

9) koszty pracy i koszty zarządzania,

10) potencjał wiedzy,

11) kapitał ludzki.

Na podstawie tej makiety przeprowadza się zasadnicze prace identyfikacyjne, związane z opracowaniem definicji, metod i formuł pomiarowych oraz empirycznej prezentacji wyników rozpoznania w postaci raportów identyfikacyjnych.

\subsection{Funkcja modelowania wzorcującego}

Modelowanie wzorcujące to funkcja badawcza, która polega na opracowaniu oryginalnych i efektywnych koncepcji teoretycznych lub konkretnych rozwiązań praktycznych, opartych na hipotezach idealizacji przedmiotu modelowania lub na podstawie przyjętych założeń usprawniania istniejącego rozwiązania. 
Idealizacja, będąca jednym z dwóch punktów wyjścia procesu modelowania, polega na formułowaniu pewnych hipotez, które dotyczą kształtowania różnych zjawisk, procesów, zależności, cech itp. w warunkach doskonałych lub osiągalnych. Podstawą idealizacji jest oczywiście sprecyzowanie celów modelowania, natomiast rozwiązanie modelu idealnego ma wskazywać zbiór jakichś wielkości, które będą charakteryzować badane zjawisko lub system. Ponadto model idealny ma wyznaczać tendencje określające reakcje lub zachowanie się - w ustalonych warunkach - jakiegoś teoretycznie wyobrażalnego obiektu lub systemu.

Idealizacja nie sprowadza się do tworzenia fantazyjnej abstrakcji, ale koncepcji teoretycznych formułowanych dla warunków doskonałych lub osiągalnych. Postępowanie idealizacyjne dopuszcza przy tym, że na danym etapie rozwoju naukowego i technicznego pewne warunki mogą być niezrealizowane. Model idealny może być również opracowany przy założeniu abstrahowania od warunków, a jego rozwiązaniem będzie jakaś zasada lub formuła o mniej lub bardziej ogólnym charakterze, wykorzystywana następnie w budowie modelu skonkretyzowanego.

Założenia usprawniania istniejącego rozwiązania dotyczą szczególnej sytuacji: podstawą zbudowania modelu jest odwzorowanie istniejącego już systemu. Kierunki i możliwości zmian w strukturze i funkcjonowaniu badanego systemu ujmuje się w założeniach usprawniania, a więc w stwierdzeniach, które wskazują na ograniczenia i warunki sprzyjające, a także stanowią wytyczne, które należy uwzględnić przy tworzeniu modelu jako przyszłego rozwiązania usprawnionego.

Rezultatem modelowania ma być wzorzec, a więc takie rozwiązanie, które wyraża nową jakość, a więc charakteryzuje się wyróżniającymi cechami. Ta nowa jakość jest określona przez odkrycie swoistych własności badanego przedmiotu lub przez wskazanie jego walorów. Dotyczyć może ona także samej koncepcji badania i stosowanych metod [Lisiński 2016]. Wzorzec może być zarówno rozwiązaniem całkowicie nowatorskim, jak i usprawnieniem istniejącego już systemu. Opracowanie wzorców jest wymagane zarówno dla potrzeb oceny sprawdzającej w diagnozie, jak i dla potrzeb poszukiwania rozwiązań projektowych w analizie prospektywnej [Lichtarski 2015].

Wskazanie wartości wzorcowych należy do istotnych czynności w metodologii projektowania. Wartości wzorcowe tworzą pewien system oceny będący wielokryterialnym układem wartościującym. Wzorce mogą mieć charakter normatywny lub postulatywny.

Wzorce normatywne są wyrażone przez wielkości z góry dane (parametry, charakterystyki), które traktuje się jako optymalne lub suboptymalne. Są to wielkości teoretyczne lub doświadczalne, bądź ustalone w sposób obligatoryjny jako wielkości zadane (planowane). Uznaje się je z założenia za wielkości ekstremalne, których przekroczenie lub nieosiągnięcie jest mankamentem. Wzorce 
normatywne są również określone jako nominanty. Zamiast nominant można stosować również przedziały referencyjne.

Natomiast wzorce postulatywne przyjmują dwojaką postać:

- jedna to stymulanty, czyli wielkości, dla których pożądana jest tendencja wzrostowa,

- druga to destymulanty, czyli wielkości, dla których pożądana jest tendencja spadkowa.

Różnica między wzorcami normatywnymi (nominantami) a postulatywnymi (stymulantami i destymulantami) polega na tym, że dla wzorców normatywnych odchylenie w górę lub w dół jest oceniane negatywnie, zaś dla wzorców postulatywnych każda sytuacja wzrostu wartości stymulant jest traktowana pozytywnie i analogicznie dodatnio jest oceniany każdy przypadek spadku wartości destymulant.

Najbardziej charakterystyczną funkcją niniejszego etapu jest skoncentrowanie się na znalezieniu benchmarków, czyli punktów odniesienia dla oceny możliwości i rezultatów własnego działania (np. w zakresie konkurencyjności, sprzedaży, poziomu technologii, jakości i niezawodności wyrobów, efektywności ekonomicznej i organizacyjnej procesów, produktywności, kosztów pracy). Benchmarki zatem to normy, optymalne wskaźniki, które stanowią probierz wyróżniającego działania.

Benchmarki są wzorcami, które stanowią rezultat postępowania badawczego zwanego dalej benchmarkingiem. Koncepcja ta sprowadza się do wyszukiwania najlepszych parametrów (charakterystyk) ze zbioru efektywnych i uznanych rozwiązań organizacyjnych, ekonomicznych, technicznych i innych, stanowiących wzorce dla własnej działalności. Wykorzystanie doświadczeń i osiągnięć wyróżniających się podmiotów, uczenie się od liderów stanowią uniwersalną wytyczną dla doskonalenia się.

Benchmarking można podzielić na następujące rodzaje [Martyniak 2002, Ziębicki 2007]:

- benchmarking wewnętrzny: odnosi się do porównań między jednostkami organizacyjnymi przedsiębiorstwa (a także między stanowiskami pracy) i polega na wypracowaniu własnej, autonomicznej formuły wzorców;

- benchmarking konkurencyjny: wykorzystuje dostępne rozwiązania modelowe, zaczerpnięte od rywali (możliwa jest także kooperacja konkurencyjnych podmiotów),

- benchmarking funkcjonalny: dotyczy wzorców realizacji określonych funkcji (np. technicznych, logistycznych, organizacyjnych), wypracowanych poza własnym sektorem, a więc w innych dziedzinach gospodarowania.

Wskazane uwarunkowania benchmarkingu upoważniają do stwierdzenia, że jest to podejście uniwersalne, o wielorakich zastosowaniach. Natomiast metodyka 
benchmarkingu cechuje się stosunkowo znaczną odrębnością od innych koncepcji metodologicznych.

Przykładem benchmarków wewnętrznych są: strategie (programy, plany), rozwiązania organizacyjne, retrospektywne lub prospektywne, istniejące i już dostępne wyroby i technologie, systemy zarządzania, stosowane wzorce kompetencyjne i inne. $Z$ założenia traktuje się je jako rozwiązania wyróżniające się przede wszystkim pod względem ekonomicznym, organizacyjnym, personalnym, informacyjnym, techniczno-produkcyjnym, a więc mając na uwadze przedstawione wcześniej wielowymiarowe ujęcie rozwoju przedsiębiorstwa.

Benchmarki zewnętrzne mają podobne odmiany rodzajowe jak benchmarki wewnętrzne, natomiast mogą się różnić w sposób zasadniczy poziomem rozwiązania, a więc kategorią. Dotyczy to uniwersalnych i specjalistycznych funkcji (parametrów, norm, wskaźników).

Oprócz benchmarków wyróżnia się również: wzorce idealne, użytkowe, sytuacyjne, aprioryczne.

Wzorce idealne to rozwiązania teoretyczne lub empiryczne uzyskane w warunkach doskonałych. Powstają one w procesach badawczych, w laboratoriach, na stanowiskach doświadczalnych.

Wzorce użytkowe są przygotowywane jako prace wdrożeniowe i opierają się na badaniach podstawowych.

Wzorce sytuacyjne to te, które opracowuje się jako koncepcje okazjonalne, odpowiadające jakimś sytuacjom szczególnym. Mogą to być sytuacje sprzyjające rozwojowi bądź przeciwnie, stanowiące zagrożenia. Wówczas jako modele-wzorce opracowuje się rozwiązania elastyczne, charakteryzujące się kreatywnością lub adaptacyjnością (zdolnością do zabezpieczania się przed destrukcją)².

Wzorce aprioryczne są konstruktami pojęciowymi, które wyrażają - z formalnego punktu widzenia - poznanie niezależne od doświadczenia. W istocie są to wytwory quasi-aprioryczne częściowo oparte na faktach.

\subsection{Funkcja diagnozy}

Diagnoza w metodologii projektowania systemów organizacyjnych ma rolę wartościującą, bowiem jej istotą jest generalnie rozumiana ocena stanu faktycznego przedmiotu badania. Wyniki tej oceny to ustalenia diagnostyczne, wskazujące na zakres i głębokość zmian, które będą uwzględnione w zasadniczym procesie projektowania [Mikołajczyk 2003]. Analiza diagnostyczna jest zatem podstawą formułowania przesłanek dla doskonalenia badanego systemu [Czekaj 2013, Metody i techniki diagnozowania... 1997].

${ }^{2}$ Wzorce sytuacyjne mieszczą się w szerokiej klasie planowania scenariuszowego [Chermack 2011, Voros 2003]. 
Przedstawiona wykładnia diagnozy ma charakter ogólny, natomiast właściwy dla niej rozwinięty zakres postępowania analitycznego zawiera szereg funkcji szczegółowych, które składają się na cykl procesu badawczego (tabela 4).

Tabela 4. Cykl procesu badawczego w diagnozie (ujęcie ramowe)

\begin{tabular}{|l|}
\hline \multicolumn{1}{|c|}{ Wyszczególnienie } \\
\hline 1. Ustalenie celu i przedmiotu badania \\
2. Wstępny dobór rodzajowy i ilościowy kryteriów oceny \\
3. Ocena stanu faktycznego \\
3.1. Opracowanie ostatecznej listy kryteriów oceny (zbiorczego probierza oceny) \\
3.2. Ustalenie wielkości wzorcowych dla danej listy kryteriów oceny \\
3.3. Analiza progowa w ocenie stanu faktycznego \\
3.4. Przeprowadzenie jednokryterialnej oceny przedmiotu badania dla danej listy kryte- \\
riów oceny \\
3.5. Ocena agregatowa przedmiotu badania (prosta, ważona) \\
4. Kategoryzacja oceny stanu faktycznego \\
5. Analiza przyczynowa \\
6. Badania porównawcze (dynamiczne, przestrzenne)
\end{tabular}

Źródło: opracowanie własne.

Zasadniczą funkcją szczegółową przedstawionego cyklu procesu badawczego jest - jak już wcześniej podkreślono - ocena stanu faktycznego. W tym przypadku jest to tzw. ocena sprawdzająca, której formuła jest wyrażona przez odniesienie wartości charakterystycznych stanu faktycznego do wartości wzorcowych (modelu-wzorca) ${ }^{3}$. Wartości charakterystyczne stanowią konkretne wyniki pomiaru, jakie są właściwe dla zastosowanych kryteriów oceny. Natomiast w diagnozie wzorzec jest odniesieniem dla oceny faktycznego stopnia sprawności (efektywności) badanego systemu lub stopnia skuteczności działania w określonych procesach. Inna jest zaś rola wzorca w analizie prospektywnej.

\subsection{Funkcja analizy prospektywnej}

Funkcja analizy prospektywnej należy do projektowania zasadniczego, poprzedzając podejmowanie decyzji projektowych. Analiza prospektywna jest funkcją będącą postępowaniem badawczym o charakterze innowacyjnym, którego podstawę tworzą kompetencje intelektualne (wiedza) człowieka, jego doświadczenie i umiejętności. Wyróżnikami tych kompetencji są:

${ }^{3}$ Od oceny sprawdzającej odróżnia się ocenę profilową. Ta ostatnia wskazuje jedynie na pozytywny lub negatywny sens wyników pomiaru stanu faktycznego systemu (ewentualnie tendencji w funkcjonowaniu systemu), nie określa natomiast stopnia sprawności (efektywności) systemu czy też stopnia skuteczności działania w procesach. 
1) predyspozycje poznawcze człowieka,

2) rozumienie istoty badanego fragmentu rzeczywistości, jej atrybutów i zachodzących w niej relacji,

3) zdolności do transformacji struktur i procesów,

4) potencjał kreatywności w tworzeniu rozwiązań przyszłościowych (modeli i projektów wdrożeniowych) oraz umiejętność opracowania wariantów projektowych.

Przedstawiona interpretacja wyraża sens ogólny analizy prospektywnej, zaś jej funkcje szczegółowe są określone w cyklu postępowania badawczego (tabela 5).

Tabela 5. Cykl procesu badawczego w analizie prospektywnej

\begin{tabular}{|l|}
\hline \multicolumn{1}{|c|}{ Wyszczególnienie } \\
\hline 1. Sformułowanie tematu i celu ogólnego projektu \\
2. Opracowanie koncepcji modelowej \\
3. Definiowanie projektu: \\
3.1. Interpretacja tematu projektu \\
3.2. Zdefiniowanie zakresu przedmiotowego (rzeczowego) projektu \\
3.3. Określenie zakresu funkcjonalnego projektu \\
4. Operacjonizacja opisu przedmiotu projektowania \\
5. Określenie trwałości eksploatacyjnej projektowanego systemu oraz ocena poziomu jego \\
innowacyjności \\
6. Planowanie eksperymentu \\
7. Opracowanie projektu wstępnego \\
8. Wariantowanie rozwiązań w perspektywie krótko- i długoterminowej
\end{tabular}

Źródło: opracowanie własne.

W przedstawionym ujęciu analizy prospektywnej należy podkreślić funkcję szczegółową określoną jako opracowanie koncepcji modelowej (inaczej zamysłu twórczego). Ta koncepcja modelowa to wzorzec ogólny opracowany w konwencji ramowej. W tym przypadku wzorzec jest czynnikiem ukierunkowującym poszukiwania wariantowych rozwiązań projektowych.

\subsection{Funkcja podejmowania decyzji projektowych}

Istotą funkcji podejmowania decyzji projektowych jest przygotowanie poprawnej i zobiektywizowanej oceny efektywności poszczególnych wariantów projektowych ${ }^{4}$. Ocena ta, jej wykładnia oraz uzasadnienie stanowią integralną część projektowania zasadniczego i jest wyrazem kwalifikacji rozwiązań projektowych. Szczegółowe

${ }^{4}$ Ocena efektywności dotyczy także rozwiązań bezalternatywnych (w odniesieniu zarówno do projektów usprawniających, jak i bazowych). 
funkcje podejmowania decyzji projektowych przedstawia tabela 6 . Listę tych funkcji poszerzono o czynności zarządzania zespołem projektowym.

Tabela 6. Cykl procesu badawczego w podejmowaniu decyzji projektowych

\begin{tabular}{|l|}
\multicolumn{1}{|c|}{ Wyszczególnienie } \\
\hline 1. Opracowanie zbioru kryteriów wyboru \\
2. Wybór racjonalnego (optymalnego) wariantu projektowego \\
2.1. Ustalenie formuły porównawczej na podstawie najlepszych parametrów poszczegól- \\
nych wariantów projektowych \\
2.2. Analiza progowa wariantów projektowych \\
2.3. Przeprowadzenie jednokryterialnej oceny wariantów projektowych \\
2.4. Ocena agregatowa wariantów projektowych (prosta, ważona) \\
3. Przeprowadzenie uzgodnień i korekt (podjęcie ostatecznych decyzji projektowych) \\
4. Projektowanie szczegółowe \\
5. Monitorowanie, nadzór i rozliczanie zadań \\
6. Koordynowanie pracy projektantów \\
7. Organizacja systemu informacyjnego w zakresie projektowanego systemu \\
8. Komunikacja w zespole projektowym \\
9. Motywacja w pracy zespołowej
\end{tabular}

Źródło: opracowanie własne.

\section{Projektowanie usprawniające i bazowe}

Projektowanie usprawniające dotyczy systemów istniejących i jest ukierunkowane na eliminację stwierdzonych dysfunkcji (wad) w stosowanych rozwiązaniach względnie ma na celu ich doskonalenie. Specyfika tego typu projektowania wyraża się m.in. w tym, że podstawowe znaczenie w usprawnianiu ma identyfikacja, diagnoza i programowanie zmian. Te trzy wyróżnione procesy składają się na prace analityczno-badawcze, które wytyczają obszar poszukiwań efektywnych rozwiązań projektowych.

Projektowanie bazowe odnosi się do nowo tworzonych systemów, a jego podstawowe cechy charakterystyczne są następujące:

1) opiera się na własnych, specyficznych kanonach i koncepcji modelowej,

2) jest reprezentowane przez podejście systemowe (całościowe),

3) stosuje metodologię budowy modeli-wzorców.

Własne, specyficzne kanony projektowania bazowego są ogólnymi zasadami konstrukcyjnymi, wedle których twórca (projektant, planista, analityk) kreuje koncepcję modelową. Są to więc normy będące wytycznymi, które przyjmuje się w poszukiwaniu rozwiązania określonego zadania projektowego. Takim przykładowym zbiorem kanonów są następujące wytyczne projektowania systemów ekonomicznych i organizacyjnych: specjalizacja produkcji, dywersyfikacja 
programu sprzedaży, ekonomizacja skali produkcji, globalizacja produkcji i rynku, koncentracja produkcji i kapitału, ekonomiczny podział pracy, outsourcing funkcji pomocniczych, tworzenie elastycznych struktur sieciowych, optymalizacja ekonomiczna struktur organizacyjnych, decentralizacja zarządzania, integracja funkcjonalna systemów zarządzania, algorytmizacja procesów decyzyjnych i kontrolnych.

Kanony stanowią nadrzędne dyrektywy dla racjonalnego projektowania i wyrażają zarazem orientację metodologiczną i praktyczną twórcy, która w każdym indywidualnym przypadku może być odmienna. Ta odmienność jest tym bardziej wyrazista, w im większym stopniu ujawniają się antynomie między poszczególnymi kanonami. Na przykład takimi przeciwstawnymi kanonami są: specjalizacja i dywersyfikacja, koncentracja i podział, globalizacja produkcyjno-organizacyjna i tworzenie elastycznych struktur sieciowych, decentralizacja i centralizacja, projektowanie układów jednorodnych pod względem funkcjonalnym i projektowanie układów zintegrowanych (wielofunkcyjnych).

Podkreślona tu antynomiczność kanonów nie może być jednak traktowana w sposób bezwzględnie alternatywny, ale powinna być rozumiana w sensie fakultatywnym, to jest w takim, który wiąże poszczególne kanony z sytuacjami zewnętrznymi i uwarunkowaniami wewnętrznymi systemu. Oznacza to, że kontekst będzie stanowił kryterium rozstrzygające o wyborze określonego kanonu, w związku z potrzebą sformułowania koncepcji modelowej.

Koncepcja modelowa to wizja rozwiązania zadania projektowego, którą wyraża z jednej strony prognoza rzeczywistości w bliższej lub dalszej perspektywie czasowej, z drugiej zaś pomysł i ogólne ujęcie wytworu projektowania. Zakłada się przy tym, iż koncepcja modelowa (lub krócej: model) jest wzorcem, bez względu na poziom idealizacji lub konkretyzacji.

Podejście systemowe traktowane jest jako immanentny wyróżnik projektowania bazowego i w sensie obiegowym stanowi strategię całościowego postępowania badawczego. W podejściu systemowym znajduje zastosowanie w całej rozciągłości dyrektywa integracji, czyli syntezy funkcji (działań, własności). T. Kotarbiński, odnosząc integrację do syntezy działań, definiuje to pojęcie jako „scalenie czynności składowych w całość [podkr. A.S.] jak najprzydatniejszą do celu" [Kotarbiński 1975, s. 202 i n.].

To scalanie powinno respektować dwa generalne postulaty: jeden to włączanie do całości wszystkiego, co niezbędne, drugi zaś to niewłączanie do całości lub usuwanie z całości wszystkiego, co zbędne [Kotarbiński 1975, s. 202 i n.]. Całościowy sens podejścia systemowego nie może być jednak ograniczony tylko do działań (procesów, procedur), ale trzeba go również odnieść do wszelkich obiektów, rozpatrywanych w sensie statycznym. Wówczas integracja będzie uniwersalnym kanonem projektowania bazowego (a także usprawniającego). 
Metodologia budowy modeli-wzorców to niezbędna determinanta projektowania bazowego. W odróżnieniu od modeli-odwzorowań, tworzenie i stosowanie modeli-wzorców jest związane przede wszystkim z poszukiwaniem nowatorskich rozwiązań naukowych i technicznych. Modele, bez względu na to, czy są konkretne, czy też abstrakcyjne, mają odgrywać rolę normatywów lub postulatów. Tworzy się je w celach porównawczych w badaniach diagnostycznych oraz na potrzeby szeroko pojmowanych prac planistyczno-projektowych. W tym ostatnim przypadku modele w stosunku do planów lub projektów są ich oryginałami, albowiem wyrażają jakieś rozwiązanie pierwotne. Modele podlegają weryfikacji i konkretyzacji podczas realizacji założonego przedsięwzięcia.

Modele mogą być zarówno rozwiązaniami całkowicie nowatorskimi (idealnymi), jak i usprawnieniami istniejącego już systemu.

\section{Szczegółowe funkcje badawcze i administracyjne w procesie projektowo-realizacyjnym}

Proces projektowo-realizacyjny opiera się na uniwersalnym schemacie metodyki badań, dotyczącej tak diagnostyki, jak projektowania. W odniesieniu jednak do konkretnego typu przedmiotu badania schemat ten musi być w odpowiedni sposób modyfikowany i uściślany. Uzasadnia się to przede wszystkim potrzebą opracowania szczegółowych metod analitycznych, w związku z przygotowaniem wersji użytkowej ekspertyzy lub projektu szczegółowego.

Sporządzenie projektu wymaga przeprowadzenia całego szeregu prac studialnych, których wyniki będą ukierunkowywać ostateczne rozwiązania. Są to np. czynności identyfikacyjne, badania porównawcze, formalizacja systemowa, a także - w pewnych wypadkach - studia historyczne i teoriopoznawcze [Podstawy metodologii badań... 2015].

Całość postępowania w procesie projektowo-realizacyjnym została przedstawiona $\mathrm{w}$ tabeli 7 . W zakresie poszczególnych faz i etapów pomieszczono szczegółowe funkcje badawcze i administracyjne. Należy przy tym dodać, że w konkretnych zadaniach projektowych lista tych funkcji może zostać zredukowana lub rozszerzona.

Tabela 7. Proces projektowo-realizacyjny

Wyszczególnienie

I. Faza prac analityczno-badawczych (w projektowaniu usprawniającym)

1. Identyfikacja stanu faktycznego systemu

2. Diagnoza

3. Programowanie zmian

lub 
cd. tabeli 7

Wyszczególnienie

I. Faza prac analityczno-badawczych (w projektowaniu bazowym)

1. Analiza sytuacyjna

2. Projektowanie systemu celów

3. Opracowanie koncepcji modelowej

II. Faza planowania przebiegu i zasobów projektu

1. Planowanie cyklu projektowo-realizacyjnego

2. Przygotowanie studium wykonalności

3. Organizacja systemu zarządzania projektami

4. Opracowanie harmonogramów

5. Kosztorysowanie

6. Budżetowanie

7. Kontrola

8. Implementacja informatycznych narzędzi zarządzania projektami

III. Faza projektowania zasadniczego

Etap przygotowawczy

1. Definiowanie projektu

2. Sformułowanie założeń i zadań projektowych

3. Zestawienie parametrów przedmiotu projektowania

4. Dobór kryteriów wyboru rozwiązań projektowych

5. Obiektywizacja kryteriów wyboru rozwiązań projektowych

Etap podstawowy

6. Opracowanie projektu wstępnego i wariantowanie rozwiązań

7. Wybór wariantu racjonalnego

8. Weryfikacja projektu wstępnego

9. Podjęcie decyzji o realizacji przedsięwzięcia

10. Projektowanie szczegółowe i koordynacja projektów cząstkowych

Etap końcowy

11. Ustalenie dopuszczalnych zmian w projekcie podczas wdrożenia

12. Weryfikacja projektu szczegółowego

13. Odbiór projektu szczegółowego

IV. Faza projektowania procesu realizacji przedsięwzięcia

1. Projektowanie systemu logistycznego dla procesu wdrożeniowego

2. Projektowanie rozruchu i wstępnej eksploatacji

3. Projektowanie systemu kontroli procesu wdrożeniowego

4. Opracowanie mapy procesów operacyjnych

5. Ustalenie normatywów procesów operacyjnych

6. Planowanie operacyjne

7. Projektowanie systemu monitorowania procesów operacyjnych

V. Faza wdrożeniowa

1. Planowanie wykonawcze i organizacja wdrożenia

2. Realizacja (implementacja)

3. Rozruch i eksploatacja wstępna

VI. Faza operacyjna

1. Przebieg procesów bezpośredniego wytwarzania

2. Przebieg procesów logistycznych

3. Przebieg procesów zarządzania

Źródło: opracowanie własne. 


\section{Zakończenie}

Przedstawione w artykule funkcje badawcze i ich wymiar teoriopoznawczy stanowią podstawę metodologii pragmatycznej, ukierunkowanej na doskonalenie istniejących oraz poszukiwanie nowych metod analizy i projektowania systemów organizacyjnych. Głównymi podejściami, które dominują w zastosowaniach praktycznych, są: podejście diagnostyczno-funkcjonalne oraz podejście funkcjonalno-wzorcujące (koncepcje systemowe). Podejścia te mają częściowo charakter normatywny, częściowo zaś postulatywny i wykorzystuje się je zarówno w badaniach diagnostycznych, jak i w projektowaniu usprawniającym i bazowym.

Projektowanie systemów organizacyjnych jest zdeterminowane przez przedmiotową odrębność tej klasy systemów. Należy jednak podkreślić, że zaprezentowana koncepcja metodologiczna charakteryzuje się dużą uniwersalnością i w związku z tym może być wykorzystana także w innych obszarach i dziedzinach. Jako ważne pola badawcze warto wymienić:

- analizę i projektowanie strategii zarządzania przedsiębiorstwem [Stabryła 2015],

- projektowanie strategii zmian [Schlesinger et al. 1999, Mikołajczyk 2003],

- planowanie scenariuszowe,

- programowanie rozwoju [Durlik i Santarek 2016],

- zarządzanie procesowe,

- zarządzanie projektami [Kerzner 2015].

W szerokich badaniach diagnostycznych i projektowaniu powinno się uwzględnić zarówno szczegółowe dziedziny, jak i kompleksowe procesy makrogospodarcze, technologiczne i społeczne.

\section{Literatura}

Chermack T.J. [2011], Scenario Planning in Organizations. How to Create, Use and Asses Scenarios, Berret-Koehler Publishers, San Francisco.

Czekaj J. [2013], Metody organizatorskie w doskonaleniu systemu zarzadzania, Wydawnictwo WNT, Warszawa.

Durlik I., Santarek K. [2016], Inżynieria zarządzania III. Naukowe, techniczne i inwestycyjne przygotowanie produkcji wyrobów wysokiej techniki, C.H. Beck, Warszawa.

Gasparski W. [1970], Kryterium i metoda wyboru rozwiązania technicznego w ujęciu prakseometrycznym, PWN, Warszawa.

Gasparski W. [1978], Projektowanie. Koncepcyjne przygotowanie działań, PWN, Warszawa.

Kerzner H. [2015], Project Management 2.0, J. Wiley, Hoboken.

Kotarbiński T. [1975], Traktat o dobrej robocie, Ossolineum, Wrocław-Warszawa-Kraków. Lichtarski J. [2015], Praktyczny wymiar nauk o zarządzaniu, PWE, Warszawa. 
Lisiński M. [2016], Metody naukowe w metodologii nauk o zarzadzaniu, „Przegląd Organizacji”, $\mathrm{nr} 4$.

Martyniak Z. [1999], Metody organizacji i zarzadzania, Wydawnictwo Akademii Ekonomicznej w Krakowie, Kraków.

Martyniak Z. [2002], Nowe metody i koncepcje zarzadzania, Wydawnictwo Akademii Ekonomicznej w Krakowie, Kraków.

Metodologia projektowania systemów organizacyjnych przedsiębiorstwa [2015], red. A. Stabryła, C.H. Beck, Warszawa.

Metody i techniki diagnozowania systemu zarządzania przedsiębiorstwem [1997], red. H. Bieniok, Wydawnictwo Akademii Ekonomicznej w Katowicach, Katowice.

Mikołajczyk Z. [2001], Techniki organizatorskie w rozwiązywaniu problemów zarzadzania, PWN, Warszawa.

Mikołajczyk Z. [2003], Zarzadzanie procesami zmian w organizacjach, Wydawnictwo GWSH, Katowice.

Podstawy metodologii badań w naukach o zarzadzaniu [2015], red. W. Czakon, Wolters Kluwer, Warszawa.

Schlesinger P.F., Sathe V., Schlesinger L.A., Kotter J. [1999], Projektowanie organizacyjne, Wydawnictwo Naukowe PWN, Warszawa.

Stabryła A. [2006], Zarzadzanie projektami ekonomicznymi i organizacyjnymi, Wydawnictwo Naukowe PWN, Warszawa.

Stabryła A. [2015], Uniwersalne ujęcie metodyki projektowania i wyboru strategii zarzadzania przedsiębiorstwem [w:] Strategie w zarządzaniu organizacjami, red. J. Rokita, Wydawnictwo GWSH, Katowice.

Trzcieniecki J. [1979], Projektowanie systemów zarzadzania, PWN, Warszawa.

Voros J. [2003], A Generic Foresight Process Framework, „Foresight”, vol. 5, nr 3, https://doi.org/10.1108/14636680310698379.

Ziębicki B. [2007], Benchmarking $w$ doskonaleniu organizacji usług użyteczności publicznej, Wydawnictwo Akademii Ekonomicznej w Krakowie, Kraków.

\section{Research Functions in Designing Organisational Systems}

(Abstract)

The paper presents the characteristics of the key research functions which constitute the methodological foundation of organisational design. The following key functions are described: identification, modelling, diagnosis, prospective analysis, and project decision-making. The following issues are discussed: the science of design in the context of organisational approaches and methodologies, the characteristics of key research functions, corrective and base designing, and specific research and administrative functions in the designing and implementation process.

Keywords: identification, modelling, diagnosis, prospective analysis, project decision-making. 